\title{
Pedagang Siomay: a study on the influence of urbanization on the type of work of the head of household in Cisukadana Village, Kadugede District, Kuningan District, West Java
}

\author{
Dede Tresna Wiyanti1*, Hardian Eko Nurseto2 \\ 1 lecturer at Department of Athropology, FISIP - Universitas Padjadjaran \\ 2 lecturer at Department of Athropology, FISIP - Universitas Padjadjaran \\ *d.tresna@unpad.ac.id
}

\begin{abstract}
Kuningan regency as one of the regencies in West Java Province, is a counter magnet area. This area is expected to absorb the increase of population and give socio-economic service in urbanization process of Jakarta Metropolitan. The main pull factor in the urbanization process is the opportunity to work in the city. This causes the productive workforce go to the city. Although the economic sector that can accommodate labor from the rural is the informal sector, that did not prevent the seasonal workers from Cisukadana went to the city.

This research was conducted in Cisukadana Village, Kadugede District, Kuningan Regency. The quantitative method were used in this research. This study aims to illustrate how the urbanization process in megapolitan city of Jakarta can affect the types of work in the village of Cisukadana, Kadugede district, Kuningan regency, West Java. Based on the findings, it appears that almost half of the total household heads in Cisukadana Village are seasonal workers, working in the informal sector in Jakarta. And of the total number of workers, most of them work as pedagang siomay.
\end{abstract}

Keywords: Cisukadana, urbanization, seasonal workers.

\section{INTRODUCTION}

Java Island is an island with the highest urbanization rate in Indonesia. The rapid economic development in major cities in Java, creating the emergence of the counter magnet areas. West Java is also an area that is designated as - counter magnet area. The area is expected to absorb the increasing population and provide socio-economic service functions as a result of the de-concentration process of development of the Metropolitan Jakarta. Kuningan regency as one of the regencies in West Java Province take on the role of the function as well.
Urbanization is an important population mobility process, in addition to fertility and mortality. These three components, urbanization, fertility, and mortality, are always work in every demography process. Economic factor is a major factor in the process of urbanization. Economy serves as push and pull factors in urbanization. Therefore rural-urban migration (urbanization) is always associated with urban poverty and unemployment as the problems of rural development. The high density in certain areas in Indonesia, indicates that there has been a movement/flow of population in the economic, social and political - growth to certain area although in absolute terms natural population growth resulting from fertility decreases as 


\begin{tabular}{|c|c|c|c|c|}
\hline $\begin{array}{c}\text { Prosiding Penelitian \& } \\
\text { Pengabdian Kepada } \\
\text { Masyarakat }\end{array}$ & $\begin{array}{c}\text { e ISSN : 2581-1126 } \\
\text { p ISSN : 2442-448X }\end{array}$ & Vol 5, No: 2 & Hal: $111-116$ & Juli 2018 \\
\hline
\end{tabular}

indicated by the estimated Total Fertility Rate (TFR) of 2, 2 in 2005. Tjiptoherijanto (1999) proves the rate of urban population growth over the last two decades has shown a very rapid increase. The UN also reported that the increase of urban population in Indonesia around 65 percent is caused by migration and reclassification. And the rest is only 35 percent due to the natural growth of the inhabitants of the city itself. Meanwhile, projections made until 2025 show that the urban population in Indonesia that year will reach 57.39 percent.

Urbanization affected both cities and rural areas. There are negative impacts that should be encountered. Those impact, such as 1) urban areas will continue to attract the movement of the population in an increasing number, 2) the concentrated population will face difficulties in utilizing available employment and job opportunities due to tight competition 3) the greater potential for conflict. Another impact, 4) is rural areas will suffer losses due to the increasing loss of their more productive human resources.

Due to the urbanization, the population will continue to attract to the urban areas. It will increase population density in the city. Most of the population that come to the city are also people with low education and skill rate. This will multiply the unemployment number. The problem will continue along with the abundance of unemployment people in the city. They will fill informal sector such as become a street vendor. The competition among the unemployed will create conflict due the tight competition and turn out to be a threat for the whole society in the city. The impact is not only stroke the urban areas, it is also affected the rural areas. The population that attracted to the city are productive population. The rural areas will suffer losses their productive human resources. The loss of productive workers will affected the composition of labor division in the rural areas. This condition will also influence the work between men and women, because the division of labor in rural areas is usually influence by gender system.

The impact of urbanization to the gender based division of labor in rural areas was shown in Soreang, West Java (Wiyanti, 2015). Economic factor, in this case the urbanization that sucked men worker to off farm sector, push women to work outside their 'comfort zones'. Women starting to perform the work that considered as men's work. These are an essential changing in gender system.

Several studies also revealed that the socioeconomic and cultural aspects of the urbanization process play a major role in changing the type of works related to the agricultural sectors in rural areas (Iskandar, 1992 and 2001; Soemarwoto and Soemarwoto, 1984). Based on the results of research in Soreang and Cianjur districts in West Java in 2008 and 2014 (Wiyanti, 2015), it was found that the economic sector outside agriculture field mostly only absorbed male labor. This paper aim to see how the urbanization process affected the type of work in rural areas. Therefore, urbanization not only has impact to the urban but also rural areas.

\section{THEORETICAL FRAMEWORK}

In general urbanization is defined as the movement of the population from rural to urban areas. Urbanization is basically a change in the proportion of people living in urban areas. Besides being caused by the growth of the natural population, the growing population in an urban area can be caused also by the displacement of people from other cities as well as from rural areas. Urbanization is not merely seen as a population phenomenon, but more than that, urbanization must be viewed as a political, social, cultural and economic phenomenon. Various studies show that the more advanced the economic level of a region, the higher the urbanization level. Thus, urbanization is a natural phenomenon in line with economic development and level of welfare of the population in an area. Things that must 


\begin{tabular}{|c|c|c|c|c|}
\hline $\begin{array}{c}\text { Prosiding Penelitian \& } \\
\begin{array}{c}\text { Pengabdian Kepada } \\
\text { Masyarakat }\end{array}\end{array}$ & $\begin{array}{c}\text { e ISSN : 2581-1126 } \\
\text { p ISSN : 2442-448X }\end{array}$ & Vol 5, No: 2 & Hal: $111-116$ & Juli 2018 \\
\hline
\end{tabular}

be considered or avoided in relation to urbanization is the presence of high or excessive population concentration in a region.

Basically ubanization has a negative impact as well as a positive impact. In his paper, Tjiptoherijanto tried to explain the views of Arthur Lewis and Myrdal about the opposite effects. According to Lewis, the modern sector in urban areas is far more productive than the traditional sector usually found in rural areas. For macro purposes, in order to increase national income, Lewis suggested that unproductive workers in rural areas should move to cities and work in the modern sector. All these workforce will contribute to total national income. Instead, Myrdal then tries to provide an understanding of the negative impacts that urbanization can bring about that rural areas will lose their productive workforce, thus the agricultural sector will be hampered, due to the difficulty of finding rural labor. This condition will affect the level of agricultural productivity.

A long with the facts about urbanization, there are urbanization policy through two approaches. First, develop rural areas to be more advanced by having characteristics as urban areas known as "rural urbanization". Second, to develop new economic growth centers known as "central growth buffer zones". The first approach seeks to "accelerate" the rate of urbanization without waiting for economic growth, by doing some non-economic breakthroughs. The change in urbanization rates is expected to spur the rate of economic growth. Thus rural areas are encouraged to grow in order to have urban traits. The villagers can be categorized as "urban people" even though they are still living in an area of rural color. This is in line with the term beach tour or coastal city, agribusiness tourism village, and others. The second policy is to develop the small and medium cities that have been there to keep up with the growth of big cities and metropolises.

From the general policy as above, it appears that during this time the pattern of urban development is still based on the concept of development that emphasizes the economic aspects alone, which is shown by the construction of malls and hypermarkets and the construction of modern social facilities such as recreation centers and so forth. This is due to the government's ability to manage economic policy is still very limited and the private sector is given wide opportunity to take an active role in this matter. Thus the approach only emphasizes on the economic aspect, whereas economic growth is not able to bring maximum results. Rural development strategies such as the development of growth centers or integrated regional programs such as the concept of urban village proved less effective in preventing the flow of incoming migration to the city. Because inevitably the urbanization trend in Indonesia up to now is still happening at the level of population movement from village to town in the hope to get a better life in the city.

Cities are places with all theirs advantages of facilities, technology and accessibility into a global network center. Technological developments and modernization of the region that had been the base began to change into areas controlled by industry and services. People's consumption patterns are beginning to change that is strongly influenced by tastes and advertising that stimulate new needs. Various studies prove that the advancement of a region/city/country will enhance urbanization level. Because of the high rate of urbanization, rural areas will suffer losses due to the increasing loss of their more productive human resources. More broadly, it will greatly disrupt the growth of small and medium-sized cities. The uncontrolled urbanization, physically indicated by 1) expanding urban area due to rapid development and expanding fringe area especially in big cities and metropolitan; 2) widespread urban physical development in suburban areas that have integrated smaller towns around their core cities and formed uncontrolled conurbations; 3) increasing number of ruraltowns; 4) the occurrence of reclassification (change of rural areas into urban areas); 5) the 


\begin{tabular}{|c|c|c|c|c|}
\hline $\begin{array}{c}\text { Prosiding Penelitian \& } \\
\text { Pengabdian Kepada } \\
\text { Masyarakat }\end{array}$ & $\begin{array}{c}\text { e ISSN : 2581-1126 } \\
\text { p ISSN : 2442-448X }\end{array}$ & Vol 5, No: 2 & Hal: $111-116$ & Juli 2018 \\
\hline
\end{tabular}

growth trend of urban dwellers in metropolitan areas decreased and vice versa in the surrounding areas experienced an increase (urbanization process in rural areas).

Such developmental trends have negatively impacted the development of small and mediumsized cities: 1) excessive exploitation of natural resources around large and metropolitan cities to support and improve economic growth; 2) continuously conversion of productive agricultural land into residential, commercial and industrial areas; 3 ) the declining quality of the urban physical environment due to environmental destruction and the greater the scale of pollution; 4) declining quality of life for urban communities due to socio-economic problems and declining quality of urban basic services. Other negative impacts caused to cities in other areas are 1) over concentration of city dwellers; 2) not optimal urban economic functions, especially smallmedium-sized cities in attracting investment and place of job creation; 3) not optimal role and function of city in supporting the embodiment of system of national cities. Until now economic activities in urban areas are still many that are not synergistic with economic activity in rural areas, consequently the role of the city that is expected to provide trickle down effect would have a negative impact on rural growth. This, in turn, can make rural communities farther behind.

The urbanization actually increase the development of the urban services sector. This sector absorbs half of the available workforce. In line with the growing urban development around the city, the absorption of labor force in the agricultural sector also decreased. The biggest factor contributing to this is the conversion of productive agricultural land into residential, industrial and recreational land. The consequence is that agricultural labor will shift to the manufacturing and service sectors. In fact, the service sector becomes a sector that is quite attractive compared to the manufacturing sector. However, the formal and informal sectors show an inconsistent number. The rural areas are still dominated by agriculture and informal sectors. In addition to the available employment and employment opportunities, this is closely related to the psychosocial and socio- economic conditions of rural communities such as simple community structure, homogeneous livelihood, high kinship, non-materialist, kindship, simple social organization, and low mobility.

The classic problem faced with urbanization is always "uncontrolled urbanization". This occurs as a result of the economic systems that are very much concerned with the modernization of the city. Consequently, it is unable to provide basic needs for the urban population and villagers. The rapid flow of urbanization is also a weakness of the people who are unable to create adequate domestic markets to encourage production (both agricultural and industrial). For many developing countries, including Indonesia, development policies that ignore the agricultural sector have resulted in inadequate income growth in rural areas. On the other hand, the policy of massively importing capital-intensive technology to achieve immediate industrialization has resulted in the growth of employment opportunities in cities not matching the number of people looking for work. Thousands of rural farmers lost their land due to unfashionable agricultural mechanization, the increasing function of land caused new symptoms that caused farmers to move to fastgrowing cities, but what they expected did not became visible.

\section{METHOD}

The method used in this study is a quantitative methods. Data collection was done through census and survey with observation and interview technique. Study of references is also done by studying theory, concepts, and similar previous studies. The census conducted to all households $(\mathrm{HH})$, both male and female headed household, in Cisukadana Village, Kadugede Subdistrict, Kuningan Regency, West Java. The sampling using Lynch formula, et.al. (1974). Based on the use of the formula, the number of 


\begin{tabular}{|c|c|c|c|c|}
\hline $\begin{array}{c}\text { Prosiding Penelitian \& } \\
\begin{array}{c}\text { Pengabdian Kepada } \\
\text { Masyarakat }\end{array}\end{array}$ & $\begin{array}{c}\text { e ISSN : 2581-1126 } \\
\text { p ISSN : 2442-448X }\end{array}$ & Vol 5, No: 2 & Hal: $111-116$ & Juli 2018 \\
\hline
\end{tabular}

samples surveyed was 103. Survey data were analyzed by Statistic Program for Social Sciences (SPSS).

\section{RESULT AND DISCUSSION}

Villagers of Cisukadana based on the latest data obtained from village monographs consist of 925 people with almost equal ratios between men and women. The number of male population is 452 and the number of female population is 473 . Total head of household $(\mathrm{HH})$ in this village counted 328 with ratio $285 \mathrm{HH}$ are male headed $\mathrm{HH}$ and $43 \mathrm{HH}$ are female headed $\mathrm{HH}$. The 43 female head of household are with marriage status as widows. While the HHs who work outside the village, and only return 1-2 times a year remain in the category of male head of household. This means that the housewife is act as the head of the household, when the husband works outside the village.

In order to know the number of families whose $\mathrm{HH}$ worked outside the village, data were collected through Village Office and RT in Cisukadana Village. Based on these data, it was found that there were 152 families whose KK worked outside the village (data attached). Based on these data, it is found a significant number, ie $46.34 \%$ of the head of the households in Cisukadana village are work outside the village. All of them are male headed household.

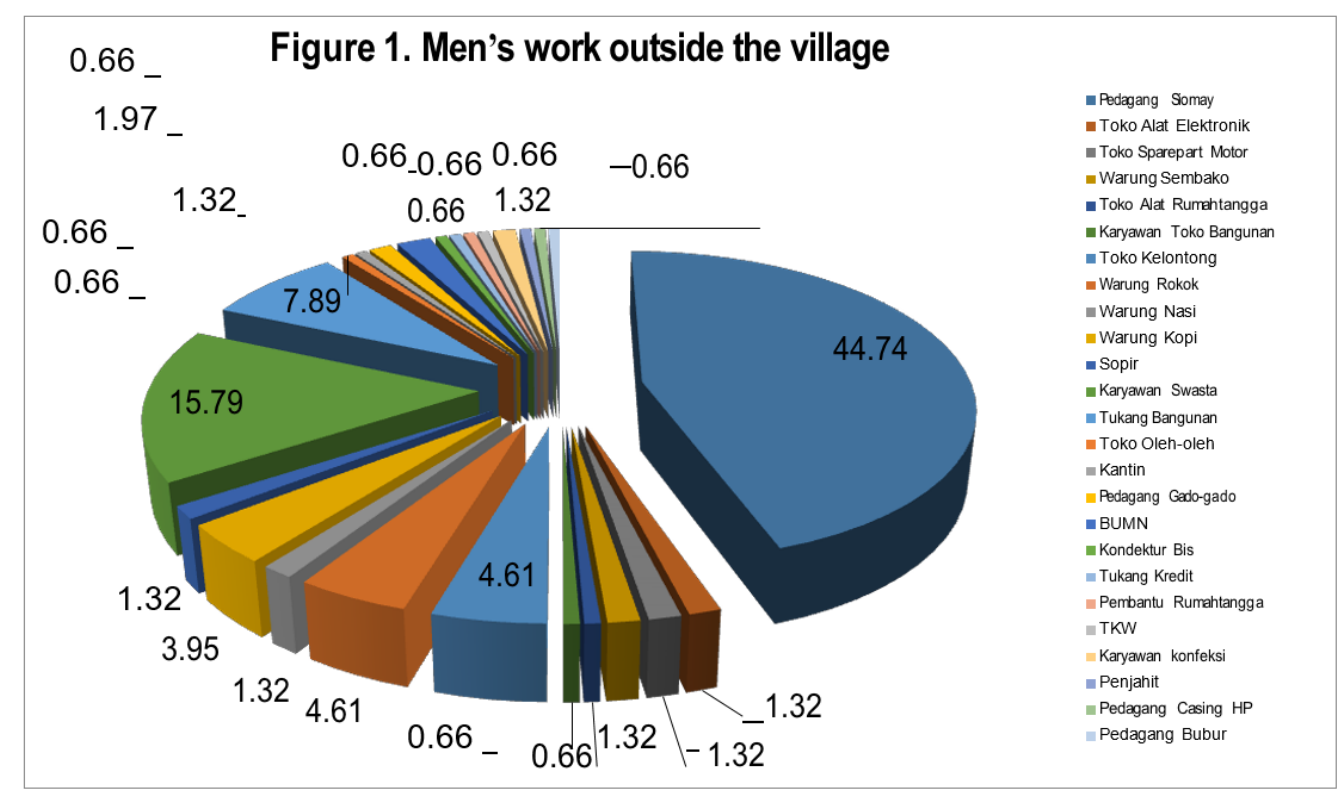

Source: Survey, 2017
The survey results also found various types of work performed by seasonal workers from Cisukadana Village. The largest percentage is the type of work of as pedagang siomay, ie $44.74 \%$. The second and third order is the type of work of private employees and tukang bangunan, respectively $15.79 \%$ and $7.89 \%$.

The data indicated that the (male) head of the household who go to the city to work are all in productive age. This will declined the population of productive worker in the village. Another fact is the type of work performed by the seasonal worker from Cisukadana Village. Almost all of them $(98.68 \%)$ are work in informal sector. This finding is support the assumption that the city has no enough capacity to absorb worker (from the rural area) in formal economic sector in urbanization.

Myrdal's assumption about the negative impact of urbanization as a cause that make the rural areas loss their productive workforce, which will hampered the agricultural sector is confirmed. But in order to maintain the agricultural land and its productivity, the villagers conducting some strategies. For example, the farmer villagers will choose the less maintenance plant. They will also shifting the planting period due to the (male) worker availability. But in some cases, they also shifting the gender values in the division of labor.

There are type of works that interchange between male and female farmer worker in the agricultural sector. 


\begin{tabular}{|c|c|c|c|c|}
\hline $\begin{array}{c}\text { Prosiding Penelitian \& } \\
\begin{array}{c}\text { Pengabdian Kepada } \\
\text { Masyarakat }\end{array}\end{array}$ & $\begin{array}{c}\text { e ISSN : 2581-1126 } \\
\text { p ISSN : 2442-448X }\end{array}$ & Vol 5, No: 2 & Hal: $111-116$ & Juli 2018 \\
\hline
\end{tabular}

\section{CONCLUSION}

As part of the region that sustains the growth of urban development in the cities, including the megapolitan Jakarta, Cisukadana Village is heavily influenced by the urbanization process. Cisukadana village is an agricultural village. But at the same time this village is strongly influenced by the development of the economy in the surrounding area. Even the economic development in Jakarta gives a significant influence for the development of this village. Men of reproductive age go to the city to work and abandon their role in managing resources in rural areas. These are leaved to the changing in type of the head of household's work in rural areas. The $46.34 \%$ of the male head of the households in Cisukadana village are work in Jakarta. Almost all of them, are working in informal sector. Become pedagang siomay in Jakarta is very appealing, many villager work in Jakarta as pedagang siomay. The loss of worker farmer in the village is pushing the shifting in the agricultural sector.

\section{REFERENCES}

Iskandar, J. (1992). Ekologi Perladangan di Indonesia: Studi Kasus dari Daerah Baduy Banten Selatan Jawa Barat. Jakarta: Djambatan.

Iskandar, J. (2001). Manusia Budaya dan Lingkungan: Kajian Ekologi Manusia. Bandung: Humaniora Utama Press, Cetakan Pertama.

Lynch, Frank (et al.). (1974). Data Gathering by Social Survey. PSSC Social Survey Series No.2.

Scolten, Elsbeth L. (1987). Female Labour in
Twentieth Century Java; European Notions Indonesian Practices. dalam Scolten, Elsbeth L. dan Anke Niehof (eds.). (1987). Indonesian Women in Focus: Past and Present Notions. Holland - USA: Foris Publication.

Soemarwoto, Otto dan Idjah Soemarwoto. (1984). The Javanesse Rural Ecosystem. Dalam A. Terry Rambo dan Percy E. Sajise (eds.), An Introduction to Human Ecology Research on Agricultural System in Southeast Asia. Los Banos: University of the Philippines.

Soemarwoto, Otto., et.al. (1985). The Talun Kebun: a Man Made Forest Fitted to Family Needs. Food and Nutrition Bulletin.

Soemarwoto, Otto. (1997). Ekologi Lingkungan Hidup dan Pembangunan. Jakarta: Djambatan, Edisi Revisi. Cetakan ketujuh.

Stoler, Ann. (1982). Struktur Kelas dan Otonomi Wanita di Pedesaan Jawa. dalam Koentjaraningrat (ed.), Masalah-masalah Pembangunan: Bunga Rampai Antropologi Terapan. Jakarta: LP3ES.

Tjiptoherijanto, Prijono. (1999). Urbanisasi dan Pengembangan Kota di Indonesia. Yogyakarta: Buletin Penelitian Kebijakan Kependudukan Volume 10 Nomor 2 Tahun 1999. PPK UGM.

Wiyanti, Dede T. (2015). Peran Perempuan dalam Sistem Kebun Talun di Desa Karamatmulya, Soreang, Jawa Barat. Bandung: Sosiohumaniora, Nopember, 2015.

Yunus, Hadi Sabari. (2005). Megapolitan: Konsep, Problematika dan Proses. Yogyakarta: Pustaka Pelajar. 